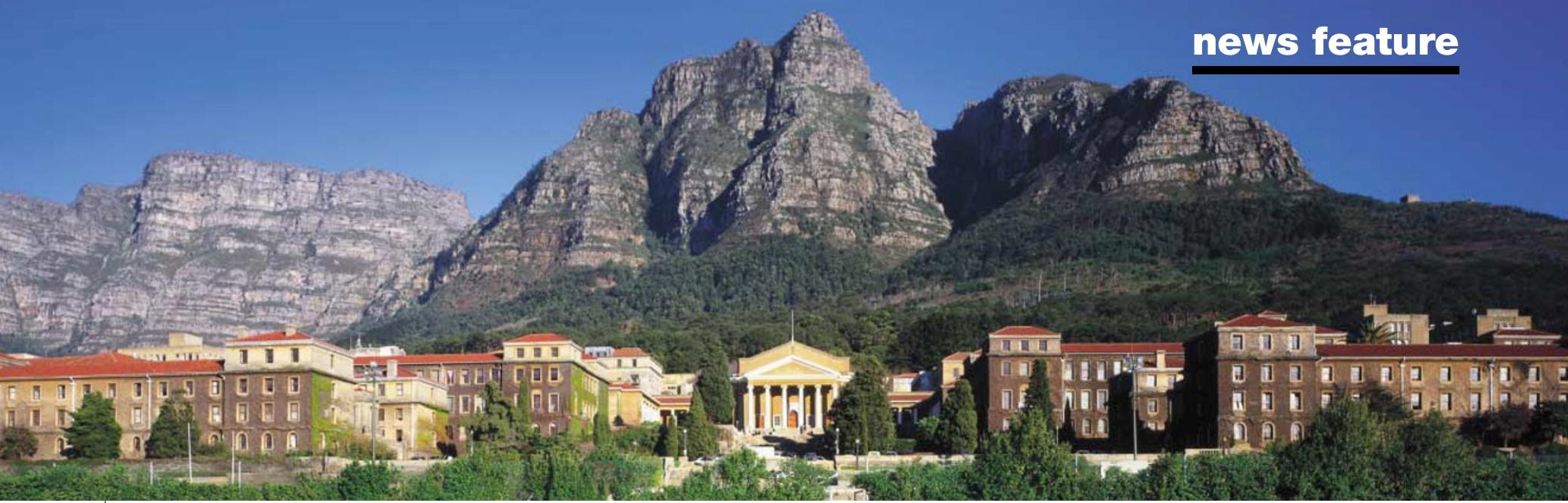

\title{
The rainbow academic nation
}

South Africa's higher-education system was designed by the architects of apartheid. So why are today's academics resisting attempts to reform it? Michael Cherry investigates.

A mid the grim news of AIDS and crime that flows out of South Africa, one success story has gone largely unreported. During the apartheid era, higher education, like most elements of South African society, was divided along racial lines. Now, less than 10 years after the country's first open elections, white students account for less than half of the enrolments at institutions that were once exclusively white.

But successful integration has brought fresh problems. As black students - a term that in South Africa encompasses black Africans, Indians and those of mixed race abandon the universities that were created for them, the government has been forced to consider merger plans. And these are proving far from popular with both historically black and historically white institutions. Places such as the historically black University of Fort Hare, which counts Nelson Mandela among its alumni, complain that their unique identity will be lost. As the South African cabinet ponders the future of its higher-education system, it is far from clear whether the successes of the 1990s can be maintained.

Current figures for enrolment in South African higher education paint an encouraging picture. Black Africans, who make up about three-quarters of the country's population, account for $60 \%$ of student numbers. Representation of mixed-race (5\%) and Indian $(7 \%)$ students also mirrors the country's racial diversity. And an increasing number of black Africans are going to historically white schools - 43\% in 2000, compared with 13\% in 1993, the year before the first free elections.

This change has meant that both institu- tions and students have had to adapt. "To change the profile and maintain standards is a tough call," says Nicola Illing, head of molecular and cell biology at the University of Cape Town. "Disadvantaged students are usually inadequately prepared.” In addition, some of the first black students to join predominantly white universities felt somewhat uncomfortable. But despite such difficulties, academics are encouraged by the progress that has been made. Half of all the postgraduates in Illing's department, for instance, are now black.

\section{Faded glory}

But it is the historically black institutions that face the biggest problems. Some of these universities have long histories, but their reputations suffered during apartheid, when they were designated as centres for specific ethnic groups. Unable to attract the best staff, many suffered from poor management and few performed any research of note.

As the racial barriers to education were slowly removed during the 1970s and 1980s, the brightest students opted - if they could afford to - for historically white institutions. The trend accelerated with the dismantling of apartheid, and enrolment in historically black universities and technikons - which focus on vocational training and perform little research — fell steadily during the 1990s. Growing economic hardship and a fall in birth rate have reduced student numbers and caused a further drop in the number of school-leavers qualifying for university entrance.

The South African government and foreign donors have attempted to revive the historically black centres by boosting their

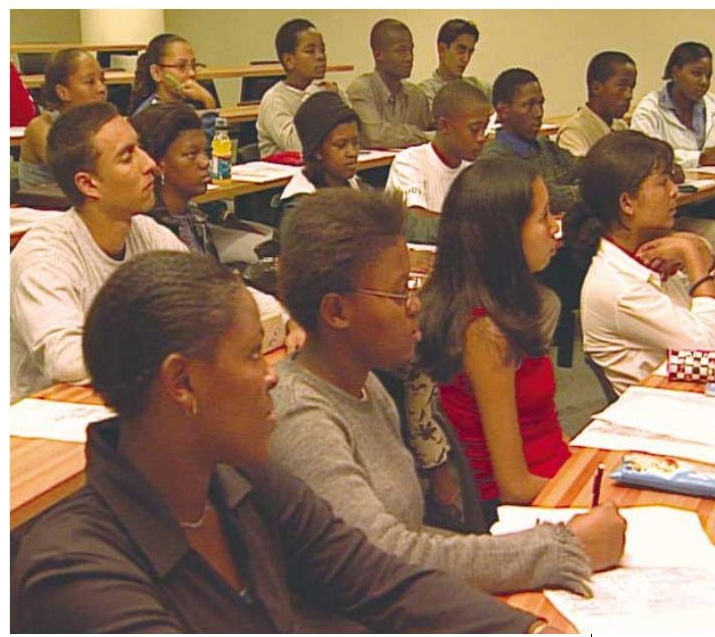

Like all historically white institutes, the University of Cape Town (top) now has many black students.

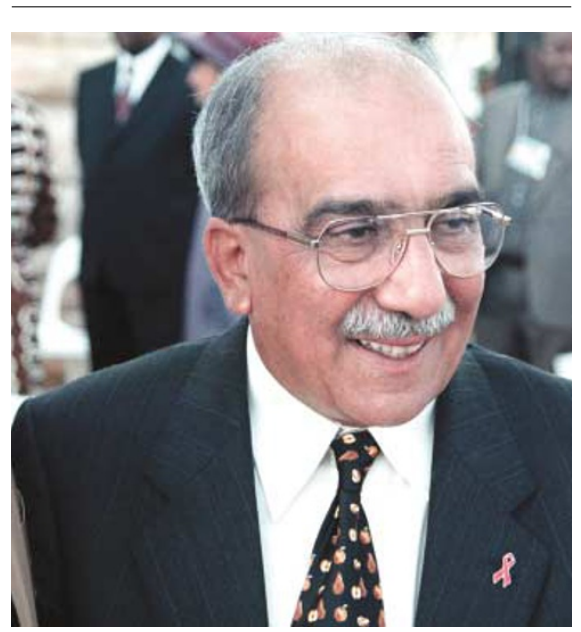

United vision: Education minister Kader Asmal plans to merge many of South Africa's universities.

previously limited research capabilities. This year, for example, the National Research Foundation, South Africa's main research funding agency, increased its funds earmarked for these institutions by $19 \%$. But most of the centres lack a culture of research, and some academics feel that money alone will not change this.

Geologist Gerhard von Gruenewaldt, the foundation's vice-president, says that funds are directed at fields where there is existing 
strength in research, but concedes that performance has, in certain cases, been disappointing. Others are more frank. "You don't build research capacity by throwing money at institutions," says David Jacobs, a zoologist at the University of Cape Town. "You do it by attracting good researchers to those institutions." But good researchers remain reluctant to join institutions that do not have strong reputations for research, so the government is being forced to find a different approach.

\section{All change}

After years of political procrastination, a plan to reform South Africa's higher education is now being discussed by ministers. In February, the National Working Group - a committee of business leaders, former university administrators and government officials set up in 2001 to advise on higher education - presented its report. Education minister Kader Asmal's recommendations, which are based on this report, were presented to the rest of the cabinet last month.

The plan envisages South Africa's 15 technikons and 21 universities being reduced to 21 institutions through a series of mergers. Fifteen of the 16 historically black institutions face mergers, in most cases with historically white counterparts. The new centres would comprise ten universities, seven technikons and four 'comprehensive institutions', which would offer both university and technikon programmes. The new institutions, argued the working group, would then be viable in terms of student numbers.

For institutions with a history of struggle, the plans are hard to accept. Fort Hare, for example, has a unique background to protect. Based in Alice in the southeast of the country, it was established in 1916 by white liberals and the black middle class. The school's tradition of 'plain thinking and high living' attracted black students from across the country and the rest of the continent. Its mainly white staff also included some black academics, and many contemporary South African politicians studied there. Although it has suffered from the 1960s onwards, when the white government ruled that only speakers of one ethnic language - Xhosa - could attend the school, Fort Hare is still proud of its liberal origins.

\section{Mixed feelings}

This history makes it difficult for Derrick Swartz, the university's vice-chancellor, to accept the proposed merger with nearby Rhodes University in Grahamstown and the medical school of the University of Transkei in Umtata, 400 kilometres to the east of Fort Hare. "The report fails to recognize the importance of institutional culture and identity - elements that play a crucial role in giving a particular character to universities across the world," he says.

Others say that the mergers risk damaging islands of excellence that exist in the historically black universities. Microbiologist Don Cowan last year left University College London for the University of the Western Cape in Cape Town. Formerly reserved for mixed-race students, this university is home to a biotechnology and bioinformatics programme that is partly funded by the National Research Foundation. Cowan says that he made the move because he felt his new university was on the way up, but now fears that a proposed merger with nearby Peninsula Technikon could be damaging. "It would be a forced blending of two structures with different teaching objectives," he says.

Some academics at historically white institutions are also wary of the plans. Those at Rhodes University question the logistics of their proposed merger with Fort Hare, as the two institutions are 100 kilometres apart. And some at the University of Port Elizabeth, which is on the country's southern coast, fear that their status will be downgraded by plans to create a comprehensive institution by merging the university with the city's technikon.

But civil servants seem keen to push Asmal's recommendations through. "We cannot allow the transformation agenda to be held to ransom by those who wish to protect their own turf," wrote Thami Mseleku, director-general of the government's education department, in the South African newspaper Business Day on 7 May.

\section{Joint efforts}

Students who have experienced both types of institution can see both sides of the problem. Victor Rambau graduated from the historically black University of Venda, situated in a rural area near the Zimbabwean border, and is now a doctoral student in population genetics at the historically white Stellenbosch University near Cape Town. He stresses the importance to rural black communities of having undergraduate institutions nearby. "But poor administration needs to be addressed," he says. "Mergers will only work if they result in effective management procedures being put in place."

In the years that the government has taken to tackle the problem, some researchers have taken it upon themselves to improve matters. Maarten de Wit, a geologist at the University of Cape Town who is regarded by many as the country's leading Earth scientist, has initiated a collaboration with the University of Venda. Backed by funding from the mining industry, de Wit helps to supervise the research projects of three students on geology degrees at Venda.

De Wit says a lack of resources at Venda means that the students have not learnt many basic experimental skills. "During the course of their degrees, they have not used a petrologic microscope or spent anywhere near enough time doing field work," he says. The scheme has the enthusiastic support of

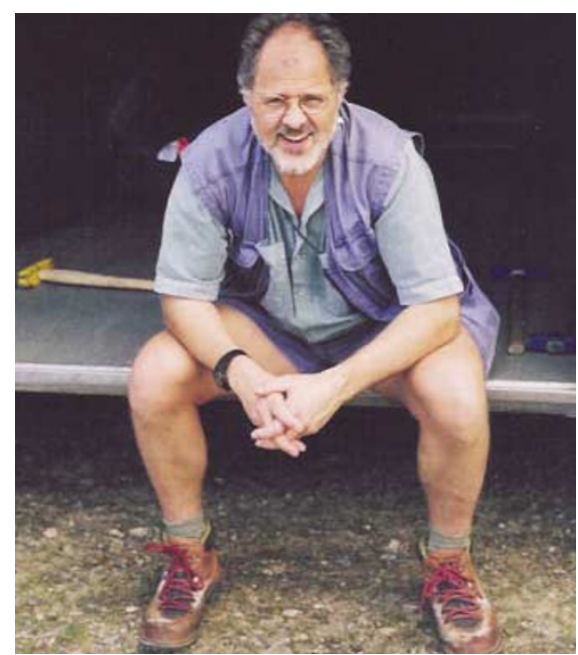

Connected: Maarten de Wit (above) has initiated collaborations between universities.

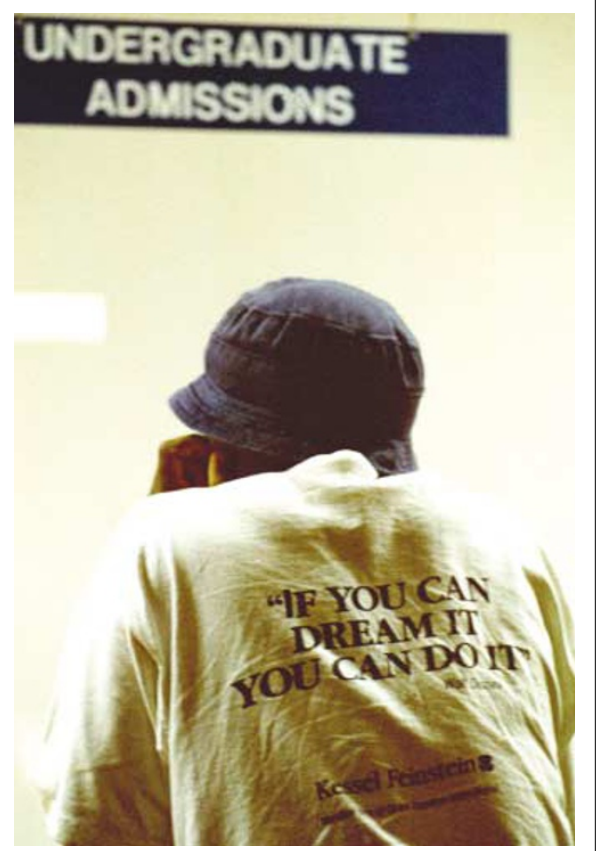

the Venda students, who say it has enabled them to access the vastly superior resources at the University of Cape Town.

Similar collaborations exist between other universities. But although the schemes can have a useful local impact, those involved know that the underlying issues will eventually have to be tackled at a national level.

With the government at last poised to do so, university and technikon leaders are lobbying to get the best for their institutions. Faced with conflicting demands, the government seems uncertain how to proceed. A decision on the merger plan had been due by early May, but has now been postponed until the end of the month. With no obvious solution on the horizon, the government is certain to disappoint some of those involved in the short term. But the long-term prize is a higher-education system that befits Africa's rainbow nation.

Michael Cherry is a zoologist at Stellenbosch University and Nature's South African contributing correspondent. http://education.pwv.gov.za/what's_new/ what's_new.htm 